\title{
Forest Insurance Market Participants' Game Behavior in China: An Analysis Based on Tripartite Dynamic Game Model
}

\author{
Ning Ma*, Yang Zuo, Kaili Liu, Yue Qi \\ School of Economics \& Management, Beijing Forestry University (China) \\ *Corresponding author: maning@biffu.edu.cn, zuovang0727@163.com,1342098411@.qq.com,qivue@bjfu.edu.cn
}

Received: June 2015

Accepted: November 2015

\section{Abstract:}

Purpose: In forest insurance market, there are three main participants including the insurance company, the forest farmer and the government. As different participant has different benefit object, there will be a complex and dynamic game relationship among all participants. The purpose of this paper is to make the game relationship among all participants in forest insurance market clear, and then to put forward some policy suggestions on the implementation of forest insurance from the view of game theory.

Design/methodology/approach: Firstly, the static game model between the insurance company and the forest farmer is set up. According to the result of static game model, it's difficult to implement forest insurance without government. Secondly, the tripartite dynamic game model among the government, the insurance company and the forest farmer is proposed, and the equilibrium solution of tripartite dynamic game model is acquired. Finally, the behavioral characteristics of all participants are analyzed according to the equilibrium solution of tripartite dynamic game model.

Findings: The government's allowance will be an important positive factor to implement forest insurance. The loss of the insurance company, which the lower insurance premium brings, can be compensated by the allowance from the government. The more the government provides allowance, the more actively the insurance company will implement forest insurance at 
a low insurance premium. In this situation, the forest farmer will be more likely to purchase the forest insurance, then the scope of forest insurance implementation will expend.

Originality/value: There is a complex and dynamic game relationship among all participants in forest insurance market. Based on the tripartite dynamic game model, to make the game relationship between each participant clear is conducive to the implementation of forest insurance market in China.

Keywords: forest insurance, insurance company, forest farmer, government

\section{Introduction}

Forests provide ecological, economic, social and aesthetic services to natural systems and humankind (Bonan, 2008). Forests and their changes are important to the regional and global carbon cycle, biodiversity and ecosystem services (Qin et al., 2015). Forest production is important for the supply of forest products needed both locally and globally, and a substantial portion of the population of the world depends on forest products for energy, construction material and paper (Nzunda, 2012). For example, wood fuel accounts for about $7 \%$ of the total energy supply in the world and in Africa $91 \%$ of energy used comes from wood fuel, which is one important form of forest products (FAO, 1999). Furthermore wood is the only renewable resource widely and economically suitable for structural and architectural purposes (Koch, 1992).

However, throughout the long production cycle, forests may be destroyed by various natural disasters such as fires, hurricanes, blizzards, earthquakes, floods, and droughts. Compared with other countries, there are more frequent occurrences of natural disasters in China (Dai, Chang \& Liu, 2015). According to the data released by State Forestry Administration of China, during the last 12 years between 2002 and 2013, there were 104,599 fire disasters affecting $1,351,248$ hectares forest area, and the area affected by disease, insect and rat pest was 129,856 thousand hectares. These forest disasters have caused a huge financial loss of forest industry in China. It is shown as Table 1. 


\begin{tabular}{|r|r|r|r|}
\hline Year & $\begin{array}{r}\text { Forest fire } \\
\text { times }\end{array}$ & $\begin{array}{r}\text { Forest fire area } \\
\text { (hectare) }\end{array}$ & $\begin{array}{r}\text { Forest Disease, Insect and Rat Pest } \\
\text { (thousand hectares) }\end{array}$ \\
\hline 2002 & 7,527 & 47,631 & 8,412 \\
\hline 2003 & 10,463 & 451,020 & 8,887 \\
\hline 2004 & 13,466 & 142,238 & 9,448 \\
\hline 2005 & 11,542 & 73,701 & 9,844 \\
\hline 2006 & 8,170 & 408,255 & 11,007 \\
\hline 2007 & 9,260 & 29,286 & 12,097 \\
\hline 2008 & 14,144 & 52,539 & 11,418 \\
\hline 2009 & 8,859 & 46,156 & 11,420 \\
\hline 2010 & 7,723 & 45,800 & 11,642 \\
\hline 2011 & 5,550 & 26,950 & 11,681 \\
\hline 2012 & 3,966 & 13,948 & 11,769 \\
\hline 2013 & 3,929 & 13,724 & 12,230 \\
\hline
\end{tabular}

Table 1. Forest disaster situation in China from 2002 to 2013

Disaster insurance program can be seen as an important risk management strategy for insurants to cope with uncertain risky environments. Forest insurance program can be considered as an effective risk-sharing policy tool to reduce the burden of risk for forest farmers. Compared with the developed countries, there will be a large potential for forest insurance in China due to the high frequency of natural disasters.

According to the report from State Forestry Administration of China (2012), in China more than $60 \%$ of the annual per capita income came from the forest production in major forest zones in 2010. Forest production is an important source of household income in these rural mountain areas. In order to resist forest natural disasters, experiments on forest insurance have been implemented in 17 provinces in China by 2012, including Fujian, Jiangxi, Hunan, Liaoning, Zhejiang, Yunnan, Guangdong, Guangxi, Sichuan, Hebei, Anhui, Henan, Hubei, Hainan, Chongqing, Guizhou and Shanxi. As the scope of experiments on forest insurance enlarged, the role of forest insurance is fairly defined. However, there are still many problems in forest insurance market, such as demand and supply scarcity, imperfect insurance policy and so on. To solve these problems is one of the main subjects in the field of forestry research currently.

\section{Forest Insurance Research Review}

According to the search results from the database like Engineering Village, Web of Science, Springer and ProQuest by using "Forestry Insurance" and "Forest Insurance", the research on forest insurance has received wide attention from many scholars.

In USA, the research on forest insurance started relatively early. Brown (1928) and Kaul (1928) took the leading in studying the forest fire insurance, and both articles concluded that the high premiums offered by insurance companies were not attractive for owners. Shepard (1937a, 1937b) was also a pioneer in this research area. Shepard (1950) noted the conditions under which standing timber can be insured at a reasonable cost and discussed the possibility that forest fire insurance could be organized on a mutual basis. 
In Sweden, forest insurance has been implemented for decades, and there are two kinds of forest insurances: against all risks and fire insurance (Angstrom, 1982). In Spain, some forest insurance programmes have appeared over the last few decades (Barreal, Loureiro \& Picos, 2014). As a case study of a forest enterprise in southwest Germany, Holecy and Hanewinkel (2006) set up a forest insurance model that can serve as a basis to calculate risk premiums to insure the risk of forest destruction.

However, in fact the purchase of insurance policy by forest owners is still an exception (Brunette, Holecy, Sedliak, Tucek \& Hanewinkel, 2015). In Spain, among the 6,224,029 hectares of insurable forest lands in 2010, only 77,103 hectares were insured against fire, i.e., $1.25 \%$ (Barreal et al., 2014). In Germany, forest insurance is in its very beginning stages (Holecy \& Hanewinkel, 2006).

Forest insurance is an effective policy to increase the net present value (NPV) of forest investments, and it has positive implications for the landowner and society (Barreal et al., 2014). Some aspects of forest insurance research have been carried out recently, such as the perception of risk of private forest owners (Blennow \& Sallnas, 2002), the role that forest products play in the famers' self-insurance (McSweeney, 2004; McSweeney, 2005) and so on.

According to the existing research above, we can see that almost all the research focus on only one aspect or two. In fact, in the forest insurance market there are three main participants:

- the insurance company as the provider;

- the forest farmer or enterprise as the demand side;

- the government.

As different participant has different benefit object, the forest farmer or enterprise hopes to get lower insurance premium, on the contrary the insurance company tends to provide higher insurance premium in most cases. In order to balance the benefit of all participants in the forest insurance market, the government will play an important role in this situation. And there will be a complex and dynamic game relationship among all participants, including the forest farmer or enterprise, the insurance company and the government.

In this paper, the tripartite dynamic game model will be set up to make the relationship among all participants in the forest insurance market clearly. The tripartite game model has been used in many fields, such as Chinese coal industry (Chen, Feng \& Cao, 2014), the price war of telecommunications in China (Wan, Wu \& Lin, 2013) and so on. Thus using the tripartite game model to analyze such complex relationships among all participants in forest insurance market will be a good way. 


\section{The Game Relationship between the Insurance Company and the Forest Farmer}

As the provider, the insurance company can affect the forest farmer's purchasing behavior by adjusting insurance premium. To make the game relationship clear, the static game model between the insurance company and the forest farmer is set up.

Hypotheses are as follows:

- The forest farmer's initial funding: W;

- The probability of forest risk: a;

- The forest farmer's loss when the risks occur: L;

- The compensation to the forest farmer when disasters occur: I;

- The forest insurance premium: $p$;

- The business cost of the insurance company to implement forest insurance: $\mathrm{K}$;

- The expected return of the forest farmer $U$, the expected return of the insurance company: V.

According to the hypotheses, the expected return of the forest farmer by purchasing the forest insurance is:

$$
U_{0}=a(W-p-L+I)+(1-a)(W-p)
$$

If the forest farmer doesn't purchase the forest insurance, the expected return is:

$$
U_{1}=a(W-L)+(1-a) W
$$

The expected return of the insurance company in forest insurance market is:

$$
V=a(p-I)+(1-a) p-K
$$

\begin{tabular}{|c|c|c|c|}
\hline & \multicolumn{2}{|c|}{ Insurance company } \\
\hline & & & Don't quote \\
\hline forest & insure & $\mathrm{U}_{0}, \mathrm{~V}$ & $U_{1}, 0$ \\
\hline farmer & Don't insure & $U_{1},-K$ & $U_{1}, 0$ \\
\hline
\end{tabular}

Game matrix between the insurance company and the forest farmer is shown as Table 2 .

Table 2. Game between the insurance company and the forest farmer

In Table 2, if you want to make (insure, quote) the equilibrium solution, you must make sure that $\mathrm{U}_{0}>\mathrm{U}_{1}$ and $\mathrm{V}>0$. 
That is

$$
a(W-p-L+I)+(1-a)(W-p)>a(W-L)+(1-a) W
$$

And

$$
V=a(p-I)+(1-a) p-K>0
$$

From the formula (4), we know that $a I-p>0$, that is $a>\frac{p}{I}$.

From the formula (5), we know that $p-a I-K>0$, that is $a<\frac{p-K}{I} \leq \frac{p}{I}$.

From the results above, we find that the insurance company's optimal strategy is conflicted with the forest farmer. From the forest farmer's point of view, only when the probability of forest risk larger than the rate of insurance premium, they will choose to insure. On the other side, only when the rate of insurance premium larger than the probability of forest risk, the insurance company will quote. In fact, in order to get more profit, the insurance company will set a high insurance premium. However, because of the lower income and weaker awareness of risk, the forest farmer tends to refuse the forest insurance at a high insurance premium. So the equilibrium solution will be (don't insure, don't quote).

\section{The Tripartite Dynamic Game Model among the Government, the Insurance Company and the Forest Farmer}

According to the analysis above, it's difficult to implement forest insurance without the government, and the government will play a very important role in forest insurance market. In this part, we will set up a tripartite dynamic game model among the government, the insurance company and the forest farmer to deeply study the complex relationship among them in forest insurance market.

Hypotheses are given as follows:

- Participants in the game: the government, the insurance company and the forest farmer.

- The sequential game actions: Firstly, the government will determine whether to provide the forest insurance allowance or not. Secondly, the insurance company will decide whether to participate in the forest insurance market actively. Finally, the forest farmer will decide whether to purchase the forest insurance.

- The participants' action space: for the government, it is to provide the forest insurance allowance or not; for the insurance company, it is to implement the forest insurance 
actively or do that negatively; for the forest farmer, it is to purchase the forest insurance or not.

- The government:

1. Rate of providing allowance: $P$, rate of not providing allowance: 1-P;

2. Cost of providing allowance: $B$;

3. Allowance for the forest farmer when provide allowance: T1;

4. Allowance for the insurance company when provide allowance: T2;

5. Economic benefits when the forest farmer purchases forest insurance: F1;

6. Environmental benefits when the forest farmer purchases forest insurance: E1;

7. Economic loss when the forest farmer doesn't purchase forest insurance: F2;

8. Environmental loss when the forest farmer doesn't purchase forest insurance: E2.

- The insurance company:

1. Rate of implementing forest insurance actively: q; rate of implementing negatively: $1-q$;

2. Cost of implementing forest insurance actively: K1;

3. Cost of implementing negatively: $\mathrm{K} 2$;

4. Benefits from the forest insurance market: $M$;

5. Compensation pay-outs when disasters occur: R;

6. Allowance from the government: T2.

- The forest farmer:

1. Rate of purchasing forest insurance: $r$; rate of no purchasing forest insurance: $1-r$;

2. Benefits of purchasing forest insurance: I;

3. Cost of purchasing forest insurance: C; 
4. Benefits of no purchasing forest insurance: $I^{\prime}$;

5. Cost of no purchasing forest insurance: $C^{\prime}$;

6. Allowance from the government: T1.

From the description of game sequence and game relationship above, we can get a game tree of participants shown as Figure 1.

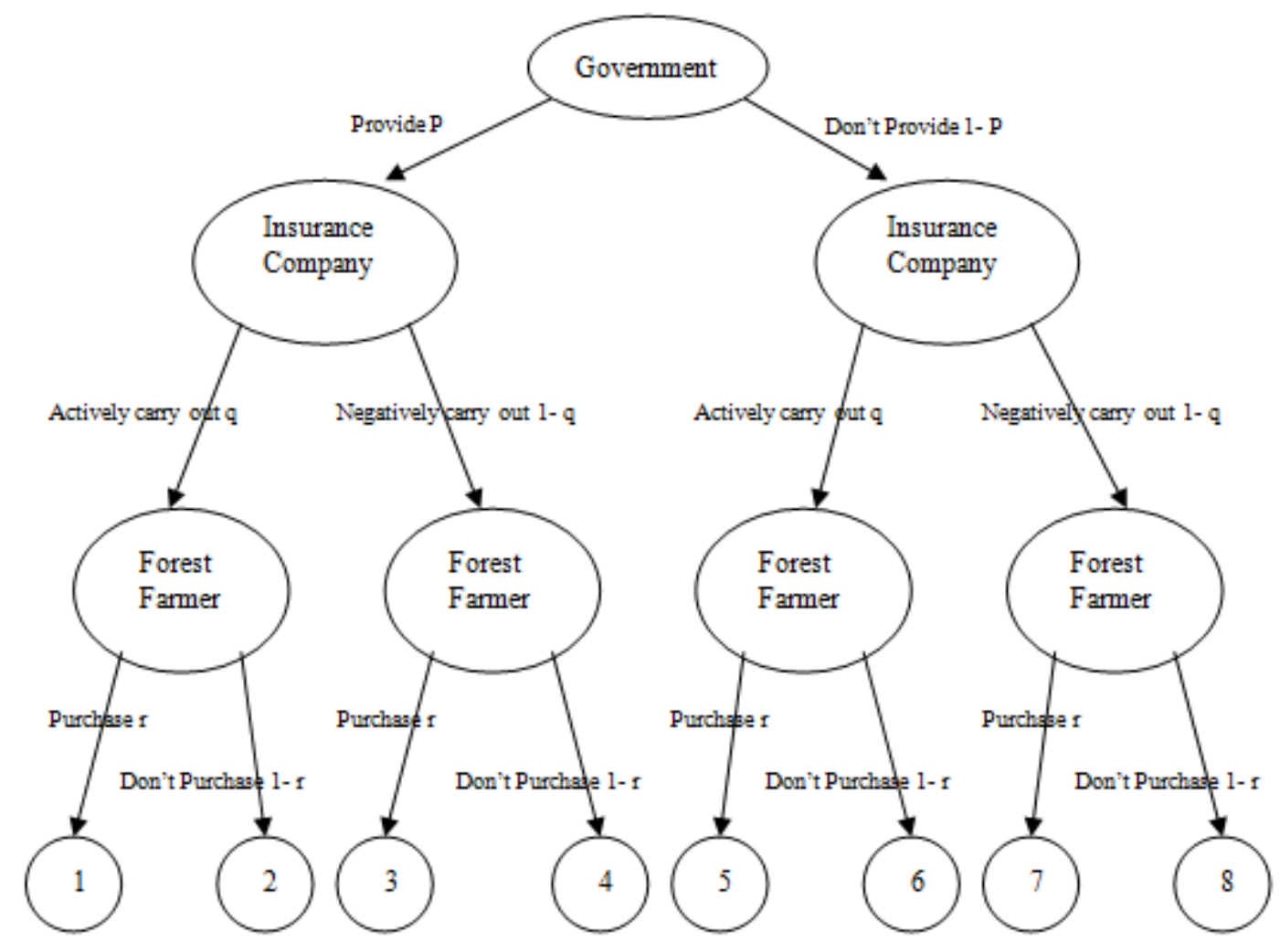

Figure 1. Game tree of participants

In Figure 1 , the nodes are expressed by numbers from 1 to 8 , meaning eight different game situations in the forest insurance market. Note 1 represents the situation when the government provides insurance allowance; the insurance company implements forest insurance actively, and the forest farmer purchases forest insurance. Note 2 represents the situation when the government provides insurance allowance; the insurance company implements forest insurance actively, but the forest farmer doesn't purchase forest insurance. Note 3 represents the situation when the government provides insurance allowance; the insurance company implements forest insurance negatively, and the forest farmer purchases forest insurance. Note 4 represents the situation when the government provides insurance allowance; the insurance company implements forest insurance negatively, but the forest farmer doesn't purchase forest insurance. From note 5 to note 8 , the forest farmer and the 
insurance company's behaviors are the same as note 1 to note 4 correspondingly, except that the government doesn't provide allowance.

We can get a payoff matrix of participants from eight notes shown as Table 3.

\begin{tabular}{|c|c|}
\hline $\begin{array}{c}\text { Sequence } \\
\text { number }\end{array}$ & payoff matrix \\
\hline 1 & {$\left[\mathrm{I}-\mathrm{C}+\mathrm{T}_{1}, \mathrm{M}-\mathrm{R}-\mathrm{K}_{1}+\mathrm{T}_{2}, \mathrm{E}_{1}+\mathrm{F}_{1}-\mathrm{B}-\mathrm{T}_{1}-\mathrm{T}_{2}\right]$} \\
\hline 2 & {$\left[\mathrm{I}^{\prime}-\mathrm{C}^{\prime}, \mathrm{T}_{2}-\mathrm{K}_{1},-\mathrm{E}_{2}-\mathrm{F}_{2}-\mathrm{B}_{2}-\mathrm{T}_{2}\right]$} \\
\hline 3 & {$\left[\mathrm{I}-\mathrm{C}+\mathrm{T}_{1}+\mathrm{T}_{2}, \mathrm{M}-\mathrm{R}-\mathrm{K}_{2}, \mathrm{E}_{1}+\mathrm{F}_{1}-\mathrm{B}-\mathrm{T}_{1}-\mathrm{T}_{2}\right]$} \\
\hline 4 & {$\left[\mathrm{I}^{\prime}-\mathrm{C}^{\prime},-\mathrm{K}_{2},-\mathrm{E}_{2}-\mathrm{F}_{2}-\mathrm{B}\right]$} \\
\hline 5 & {$\left[\mathrm{I}-\mathrm{C}, \mathrm{M}-\mathrm{R}-\mathrm{K}_{1}, \mathrm{E}_{1}+\mathrm{F}_{1}\right]$} \\
\hline 6 & {$\left[\mathrm{I}^{\prime}-\mathrm{C}^{\prime},-\mathrm{K}_{1},-\mathrm{E}_{2}-\mathrm{F}_{2}\right]$} \\
\hline 7 & {$\left[\mathrm{I}-\mathrm{C}, \mathrm{M}-\mathrm{R}-\mathrm{K}_{2}, \mathrm{E}_{1}+\mathrm{F}_{1}\right]$} \\
\hline 8 & {$\left[\mathrm{I}^{\prime}-\mathrm{C}^{\prime},-\mathrm{K}_{2},-\mathrm{E}_{2}-\mathrm{F}_{2}\right]$} \\
\hline
\end{tabular}

Table 3. Payoff matrix of participants

In Table 3, the first row is the forest farmer's payoff function, the second row is the insurance company's payoff function and the third one is the government's payoff function. The sequence numbers from 1 to 8 in Figure 1 are relating to the payoff matrix in Table 3 with the same sequence number. For example, the payoff matrix [I-C+T1, M-R-K1+T2, E1+F1-B-T1-T2], whose sequence number is 1 in Table 3, can be explained like this: under the situation when the government provides insurance allowance; the insurance company implements forest insurance actively and the forest farmer purchases forest insurance, the forest farmer's payoff matrix is $\mathrm{I}-\mathrm{C}+\mathrm{T} 1$, the insurance company's payoff matrix is M-R-K1+T2 and the government's payoff matrix is E1+F1-B-T1-T2. The rest notes from 2 to 8 can be done in the same manner.

The equilibrium solution of the dynamic game model is as follows:

- The forest farmer's payoff function:

$e_{1}=p q r\left(I-C-T_{1}\right)+p q(1-r)\left(I^{\prime}-C^{\prime}\right)+p(1-q) r\left(I-C+T_{1}+T_{2}\right)+p(1-q)(1-r)\left(I^{\prime}-C^{\prime}\right)+(1-p) q r(I-C)+(1-$ p) $q(1-r)\left(I^{\prime}-C^{\prime}\right)+(1-p)(1-q) r(I-C)+(1-p)(1-q)(1-r)\left(I^{\prime}-C^{\prime}\right)$

That is $e_{1}=p r T_{2}-p q r T_{2}+p r T_{1}+r I-r C+I^{\prime}-r I^{\prime}-C^{\prime}+r C^{\prime}$.

To maximize the forest farmer' payoff function, that is $\frac{\partial e_{1}}{\partial r}=0$ and $p T_{2}-p q T_{2}+p T_{1}+I-C+I^{\prime}-$ $I^{\prime}-C^{\prime}=0$, thus,

$$
q^{*}=\frac{(I-C)-\left(I^{\prime}-C^{\prime}\right)+p T_{2}+p T_{1}}{p T_{2}}
$$


- The insurance company's payoff function:

$e_{2}=p q r\left(M-R-K_{1}+T_{2}\right)+p q(1-r)\left(T_{2}-K_{1}\right)+p(1-q) r\left(M-R-K_{2}\right)+p(1-q)(1-r)\left(-k_{2}\right)+(1-p) q r(M-R-$

$\left.K_{1}\right)+(1-p) q(1-r)\left(-K_{1}\right)+(1-p)(1-q) r\left(M-R-K_{2}\right)+(1-p)(1-q)(1-r)\left(-K_{2}\right)$

That is $e_{2}=p q T_{2}-q K_{1}+r M-r R-K_{2}+q K_{2}$.

To maximize the insurance company' payoff function, that is $\frac{\partial e_{2}}{\partial q}=0$ and $p T_{2}-K_{1}+K_{2}=0$, thus,

$$
p^{*}=\frac{K_{1}-K_{2}}{T_{2}}
$$

- The government's payoff function:

$e_{3}=p q r\left(E_{1}+F_{1}-B-T_{1}-T_{2}\right)+p q(1-r)\left(-E_{2}-F_{2}-B-T_{2}\right)+p(1-q) r\left(E_{1}+F_{1}-B-T_{1}-T_{2}\right)+p(1-q)(1-r)\left(-E_{2}-F_{2}-\right.$

$B)+(1-p) q r\left(E_{1}+F_{1}\right)+(1-p) q(1-r)\left(-E_{2}-F_{2}\right)+(1-p)(1-q) r\left(E_{1}+F_{1}\right)+(1-p)(1-q)(1-r)\left(-E_{2}-F_{2}\right)$

That is $e_{3}=-p B+r E_{1}+r F_{1}-E_{2}-F_{2}+r E_{2}+r F_{2}-p q T_{2}+p q r T_{2}-p r T_{1}-p r T_{2}$.

To maximize the government' payoff function, that is $\frac{\partial e_{3}}{\partial p}=0$ and $-B-q T_{2}+q r T_{2}-r T_{1}-r T_{2}=0$, thus,

$$
r^{*}=\frac{B+q T_{2}}{q T_{2}-T_{1}-T_{2}}
$$

From formula (7) and (6), we know that: $q^{*}=\frac{(I-C)-\left(I^{\prime}-C^{\prime}\right)}{K_{1}-K_{2}}+\frac{T_{1}+T_{2}}{T_{2}}$.

From formula (7) and (8), we know that: $r^{*}=\frac{\left(K_{2}-K_{1}\right)\left(B+T_{2}+T_{1}\right)}{\left(I^{\prime}-C^{\prime}\right)-(I-C)}+1$

Thus, the equilibrium solution of the tripartite dynamic game model is:

$$
p^{*}, q^{*}, r^{*}=\left[\frac{K_{1}-K_{2}}{T_{2}}, \frac{(I-C)-\left(I^{\prime}-C^{\prime}\right)}{K_{1}-K_{2}}+\frac{T_{1}+T_{2}}{T_{2}}, \frac{\left(K_{2}-K_{1}\right)\left(B+T_{2}+T_{1}\right)}{\left(I^{\prime}-C^{\prime}\right)-(I-C)}+1\right]
$$

According to the equilibrium solution of the tripartite dynamic game model, the behavior characteristics of the government, the insurance company and the forest farmer are as follows:

- The intention of the government to provide the forest insurance allowance depends on the amount of allowance to the insurance company and the cost of insurance company implementing forest insurance. The cost of insurance company implementing the forest insurance actively is higher, and the amount of allowance is fewer, then the government tends to provide the forest insurance allowance more. 
- Whether the insurance company implements forest insurance actively or not, that is determined by the cost of implementing forest insurance, benefits and cost of the forest farmer and the amount of allowance from the government. Benefits of the forest farmer by purchasing forest insurance is more, the cost of the insurance company implementing forest insurance actively is lower, and the allowance from the government is more, then the insurance company will be more likely to implement forest insurance actively.

- The forest farmer's intention of purchasing forest insurance is related to all participants' behaviors. The cost of the insurance company implementing forest insurance actively is lower, the allowance from the government is more, benefits of the forest farmer purchasing forest insurance is more, then the forest farmer will tend to purchase the forest insurance more.

\section{Conclusions}

In forest insurance market, there are three main participants including the insurance company, the forest farmer and the government. The insurance company is the provider of forest insurance, and the forest farmer is the forest insurance demander. In general, the price is decided by the supply and the demand in market. If the supply is short, the price will increase; if the demand is short, the price will decrease. In fact, in forest insurance market both the supply and the demand are short. Some studies have shown that it is difficult for the insurance company to implement forest insurance at a low cost (Manley \& Watt, 2009), and also shown that the larger the insured area is, the lower the insurance premium will be (Holecy \& Hanewinkel, 2006; Pinheiro \& Ribeiro, 2013). That is to say, the more widely the forest insurance implementation is, the lower insurance premium will be.

However, at the beginning of the forest insurance implementation, the scope of forest insurance implementation is limited. In this situation, the insurance company has to set a higher insurance premium to guarantee profits, and it will expel the forest farmer from the forest insurance market. Thus, in the beginning of forest insurance market, the insurance company and the forest farmer will have inconsistent expectations for the forest insurance premium. If the insurance premium is set directly by demand and the supply in this period, the forest insurance market will shrink.

However, natural disasters are unfavorable factors for the sustainable development of forestry. Take an example of wildfires, wildfires can cause significant damage to both the forest stand and soil quality, whilst the affected growing stocks may take a long time to recover (Inbar, Wittenberg \& Tamir, 1997). The forest restoration is expensive for landowners, who may be interested in covering wildfires losses with insurance in exchange for the payment of proper 
insurance premium. The creation of proper incentives for landowners to increase the use and penetration of insurance markets in forestry (Amacher, Malik \& Haight, 2006) can become a significant tool to fight additional costs imposed by the occurrence of natural disasters.

In fact, to lower insurance premium is an effective way to attract more forest farmers to enter the forest insurance market. Thus in order to expand the forest insurance market, the government's allowance will be an important positive factor. The loss of the insurance company, which the low insurance premium brings, can be compensated by the allowance from the government. And the forest farmer can also get the allowance from the government, which will reduce the economic burden of the forest farmer on purchasing the forest insurance. The more the government provides allowance, the more actively the insurance company will implement forest insurance at a low insurance premium. In this situation, the forest farmer will be more likely to purchase the forest insurance, then the scope of forest insurance implementation will expend.

\section{Acknowledgments}

Beijing Higher Education Young Elite Teacher Project (No.YETP0777), Humanities and Social Sciences Planning Fund Supported by Chinese Ministry of Education (No.12YJAZH090), Program of Study Abroad for Young Scholar sponsored by China Scholarship Council.

\section{References}

Amacher, G., Malik, A., \& Haight, R. (2006). Reducing social losses from forest fires. Land Econ., 82, 367-383. http://dx.doi.org/10.3368/le.82.3.367

Angstrom, A. (1982). Forest insurance in Sweden. Forest Fire Prevention and Control, 7, 223-227. http://dx.doi.org/10.1007/978-94-017-1574-4_26

Barreal, J., Loureiro, M.L., \& Picos, J. (2014). On insurance as a tool for securing forest restoration after wildfires. Forest Policy and Economics, 42, 15-23. http://dx.doi.org/10.1016/j.forpol.2014.02.001

Blennow, K., \& Sallnas, O. (2002). Risk perception among non-industrial private forest owners. Scandinavian Journal of Forest Research, 17(5), 472-479. http://dx.doi.org/10.1080/028275802320435487

Bonan, G. (2008). Forests and climate change: Forcings, feedbacks, and the climate benefits of forests. Science, 320, 1444-1449. http://dx.doi.org/10.1126/science.1155121

Brown, W.R. (1928). Forest fire actuary. Journal of Forestry, 26(1), 88-90. 
Brunette, M., Holecy, J., Sedliak, M., Tucek, J., \& Hanewinkel, M. (2015). An actuarial model of forest insurance against multiple natural hazards in fir (Abies Alba Mill.) stands in Slovakia. Forest Policy and Economics, 55, 46-57. http://dx.doi.org/10.1016/j.forpol.2015.03.001

Chen, H., Feng, Q., \& Cao, J. (2014). Rent-seeking mechanism for safety supervision in the Chinese coal industry based on a tripartite game model. Energy Policy, 72, 140-145. http://dx.doi.org/10.1016/j.enpol.2014.04.017

Dai, Y., Chang, H.H., \& Liu, W. (2015). Do forest producers benefit from the forest disaster insurance program? Empirical evidence in Fujian Province of China. Forest Policy and Economics, 50, 127-133. http://dx.doi.org/10.1016/j.forpol.2014.06.001

FAO (Food and Agriculture Organization). (1999). State of the world's forests. FAO, Rome, 154.

Holecy, J., \& Hanewinkel, M. (2006). A forest management risk insurance model and its application to coniferous stands in southwest Germany. Forest Policy and Economics, 8, 161-174. http://dx.doi.org/10.1016/j.forpol.2004.05.009

Inbar, M., Wittenberg, L., \& Tamir, M. (1997). Soil erosion and forestry management after wildfire in a Mediterranean Woodland, Mt. Carmel, Israel. Int. J. Wild land Fire, 7,285-294. http://dx.doi.org/10.1071/WF9970285

Kaul, J. (1928). Report of Committee on Forest Fire Insurance of the Commercial Forestry Conference. Journal of Forestry, 26(1), 76-84.

Koch, P. (1992). Wood versus non-wood materials in U.S. residential construction: Some energy-related global implications. Forest Products Journal, 42(5), 31-42.

Manley, B., \& Watt, R. (2009). Forestry insurance, risk pooling and risk mitigation options. Report prepared for MAF Project CM-09 under MAF POL, 0809-11194.

McSweeney, K. (2004). Forest product sale as natural insurance: the effects of household characteristics and the nature of shock in eastern Honduras. Society and Natural Resources, 17(1), 39-56. http://dx.doi.org/10.1080/08941920490247245

McSweeney, K. (2005). Natural insurance, forest access, and compounded misfortune: Forest resources in smallholder coping strategies before and after Hurricane Mitch, northeastern Honduras. World Development, 33(9), 1453-1471. http://dx.doi.org/10.1016/j.worlddev.2004.10.008

Nzunda, E.F. (2012). Discrepancies between targets and achievements in industrial forest production and export in Tanzania. Forestry Studies in China, 14(3), 210-215. http://dx.doi.org/10.1007/s11632-012-0307-y 
Pinheiro, A., \& Ribeiro, N. (2013). Forest property insurance: an application to Portuguese woodlands. Int. J. Sustain. Soc, 5(3), 284-295. http://dx.doi.org/10.1504/IJSSOC.2013.054716

Qin, Y., Xiao, X., Dong, J., Zhang, G., Shimada, M., Liu, J., et al. (2015). Forest cover maps of China in 2010 from multiple approaches and data sources: PALSAR, Landsat, MODIS, FRA, and NFI. ISPRS Journal of Photogrammetry and Remote Sensing, Nov, 1-16. http://dx.doi.org/10.1016/j.isprsjprs.2015.08.010

Shepard, H.B. (1937a). Forest fire insurance in the pacific coast states. Technical Bulletins, $33(2), 111-116$.

Shepard, H.B. (1937b). Fire insurance for forests. Journal of Land \& Public Utility Economics, 13(2), 111-115. http://dx.doi.org/10.2307/3158703

Shepard, H.B. (1950). Comment on forest fire insurance. Journal of Forestry, 48(8), 348-350.

State Forestry Administration of China (2012). Development Report of Chinese Forestry in 2012. Beijing: China Forestry Press (in Chinese).

Wan, X.Y., Wu, J., \& Lin, X. (2013). Tripartite dynamic game model with incomplete information in telecommunications regulated by government. Management Science \& Engineering (ICMSE), 2013 International Conference on (20, 2282-2288). IEEE.

Journal of Industrial Engineering and Management, 2015 (www.jiem.org)

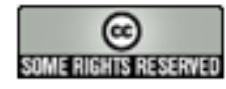

Article's contents are provided on an Attribution-Non Commercial 3.0 Creative commons license. Readers are allowed to copy, distribute and communicate article's contents, provided the author's and Journal of Industrial Engineering and Management's names are included. It must not be used for commercial purposes. To see the complete license contents, please visit http://creativecommons.org/licenses/by-nc/3.0/. 